\title{
THE LEGACY FOR THE BEGINNING OF THE MARKET ECONOMY TRANSITION IN BULGARIA
}

\author{
Venelin Terziev \\ Academician of the Russian Academy of Natural History, Moscow, Russia, \\ Prof.D.Sc. (Ec.), D.Sc. (National Security), D.Sc. (Social Activities), Ph.D., National Military \\ University, Veliko Tarnovo, Bulgaria; University of Rousse, Rousse, Bulgaria, terziev@skmat.com
}

\begin{abstract}
The adequacy and timeliness of an implemented policy are crucial for the effective support of changes in the parameters of the labour market and economic development. Considering the time delay of the effects and changes. its duration should not be overlooked in order to develop preventive measures for a timely response. Shortening the period in which the effects of the contemporary crisis are transferred on the labour market, respectively labour demand, reflects not only the degree of elasticity of labour demand to primary markets, but also the flexibility of the implemented policies. This fact has focused attention on the flexibility of labour markets and opportunities through its increase to strengthen the mobility and adaptability of the workforce to the dynamically evolving labour demand.
\end{abstract}

Keywords: labour market, employment, unemployment, social policies.

\section{INTRODUCTION}

After World War II, the existing conditions for full employment enabled almost all countries to focus their efforts on the issue of labour efficiency, the behaviour of the participants in the labour process, and the attitude towards labour. After the 1970s, substantial changes in the economic and social life were made worldwide which reflected the 'attitudes regarding labour' and the labour relations in the strict sense of the term. The growing discrepancy between labour supply and demand brought to the focus of attention the concept of labour market, in which the main emphasis was on the relationship between employers and workers. The major signs of the so called 'black economy' and „black labour market" became apparent. On the one hand, quantitative and qualitative discrepancies resulted in measures to reduce labour supply. On the other hand, they provoked measures to encourage workforce demand. The marginalization of certain population groups and the rising inflation were the major problems during that period. For the EU Member States, the USA and Japan, the period after 1980 was characterized by certain achievements in the economic growth, allowing for a corresponding increase in employment, albeit at slower rates. The nature of the structural changes in the economies showed that the use of the old methods to regulate employment and unemployment were already inadequate.

Bulgaria, as well as the other socialist countries, being subject to the idea of "full employment" for more than half a century suffered the heavy consequences of the transition period and the restructuring of the economy 
that seemed to be the most severe in the sphere of employment. Bulgaria has proved to be relatively unprepared to face the challenges of the market economy in this field due to a lack of public response towards greater personal activity, personal responsibility and entrepreneurship. The expectations for change were once again primarily related to the role of the state.

The specific objectives of labour policy and employment in particular depend on many circumstances. Theoretically, several key objectives could be formulated, considering the effects of unemployment:

- Preserving and protecting human resources as the key component of each country's forces of production;

- Integrating the new generations to the values of working life and work ethics;

- Socially equitable division of labour in society;

- Compliance with the principle according to which labour is the key factor, ensuring the security balance of personality, while the provision of social benefits only replaces or supplements the income from work;

- Preserving social peace within society;

- Solving employment problems not at the expense of higher inflation;

- Using the efforts of the state, as well as the local communities and voluntary associations when solving the problems of employment and unemployment problems.

The state and its specialized bodies should also be referred to as subjects of the employment policy in Bulgaria, namely: the Employment Agency under the Ministry of Labour and Social Policy, the National Council for Tripartite Cooperation, representing workers' organizations and employers' organizations, and the Agency for Social Assistance under the Ministry of Labour and Social Policy; at a regional level - the regional governors, municipalities, the regional employment services and labour offices. These entities are engaged in the institutionalized relations 'regarding labour' and the relations between employers and workers. To the institutionalized entities we can also refer the established and legalized private agencies and labour offices, some nongovernmental organizations which along with other social functions conduct intermediary activities such as finding employment for people at risk and participate in the implementation of projects for training, qualifying and retraining individuals suffering hardships (Georgiev, 2016; Georgiev, 2017-a).

\section{THE LEGACY FOR THE BEGINNING OF THE MARKET ECONOMY TRANSITION}

In the years of socialism, the state policy was aimed to prevent unemployment, which happened at the expense of the economic efficiency and productivity. New jobs were constantly created and all available labour resources were mobilized to participate in the production process. The mass accumulation of fixed capital and the major investments in the country's human resource development did not contribute to the stable and constant increase in productivity. The so called 'hidden unemployment' was also developed. It was related to the inefficient use of already employed workforce, loss of working hours due to various reasons, low labour intensity, etc.

By the mid-1970s the economic growth was based on the constant increase in the use of production resources (workforce, investment, raw materials and materials, energy) in proportion to the increase in production or at a faster rate. Long before the end of the 1980s, it became increasingly clear (and that is why the question was openly posed) that a further increase in production could not be ensured by the extensive method, i.e. by constantly increasing the factors of production. Attempts were made for a shift to an intensive type of development through increasing labour productivity at a faster rate in terms of resources used and production. However, the conditions for similar development were not provided - modernization of production, new technologies and equipment, and economic incentives for the employed in more productive labour. The deceleration of the economic growth rate during the $1980 \mathrm{~s}$, related to a delay and decrease in the labour productivity, increased hidden unemployment. Serious difficulties to maintain the achieved standard of living of the population also emerged.

Managers were also interested in maintaining a higher employment rate in enterprises than the economically needed one. The business category and the level of payment depended on the scale of the enterprise, including the number of people employed in it. Moreover, there was a reserve of manpower that could be used, if necessary, to fulfil or overfulfill the plan - usually at the end of the year or the five-year period. Overspending of production funds, including for salary, was not penalized (Terziev, 2019a-k).

The workforce was administratively distributed among branches, activities, sectors and economic regions. Insofar as under such conditions it could be assumed that a labour market existed, it had the following 
characteristic features (especially in the last decade of the examined period):

- Labour demand exceeded supply, i.e. the number of jobs exceeded the number of active population;

- A high level of employment of the population, including women. Practically, the entire active population that did not continue their education in full-time training or did not do military service, but were healthy enough, was engaged in economic activities, i.e. was employed;

- Relatively low wages and little differentiation in the level of payment for the different groups of employees (by education, professional training and qualification, working conditions and other factors for differentiating wages);

- A constant improvement of the level of education and professional training of employees, mainly at the expense of the younger generation, regardless of the low wages of skilled labour, very often lower than the wages of employees with a low level of education and without vocational training;

- Universal and guaranteed employment, a high degree of layoff protection until, practically, workers themselves wanted to be dismissed;

- Controlled movement of population, especially of manpower to big cities;

- Jobs were obligatory assigned to university graduates or graduates from other vocational schools (until the early 1980s);

- substantial share and priority of social benefits in enterprises in the labour costs and motivation to work in one organization or another such as opportunities for early retirement, protection against dismissal especially prior to retirement, before birth and for mothers with small children, disabled people, etc.; provision of housing or hostels by enterprises at symbolic prices, mandatory paid leave for raising young children (up to the age of 3 ) and opportunities to continue education without losing one's job; free or relatively low-priced dining in company cafeterias, cheap annual family holidays at the seaside and/or in the mountains; opportunities to buy food and other goods directly from the enterprises at lower prices; use of free medical, dental, preventive and sports services in the enterprises; use of low-priced childcare facilities at the company; grants for students, children of long-time employees of the organization, etc.

During the second half of the twentieth century Bulgaria's economy changed from typically agricultural to highly industrial. In the early 1950s the predominant share of production and of the employed was in agriculture. The collectivization of the agricultural sector during the 1960 s and the intensively pursued policy of industrialization radically changed the structure of production and employment. More than one million agricultural workers were redeployed to other sectors - mainly industry, and to a much lesser extent construction and services. The share of industrial production and employment was constantly increasing and at the end of the 1980s, by share of industrial production, investment, long-term tangible assets and the employed, Bulgaria obtained the characteristics of a typical industrial economy (Terziev, 2019a-k).

Several years prior to the beginning of the transition period, in compliance with the ongoing attempts to reform the socialist economy, the distribution of the workforce and its mobility was exempt from administrative interference. The very beginning of the transition to a market economy coincided with the realized liberalization of the movement of population and manpower - in and out of the country, between towns and villages and to big cities; wages; employment, dismissals, etc.

The first half of the 1990s was a period of economic reforms: creation and development of markets, including the labour market; a change in the pattern of employment and formation of adequate policies to cope with the social problems, arising from privatization, structural reforms and the evolved unemployment and impoverishment of the population. Since the late 1990s, a policy of integration into the EU has been pursued and related actions of strategic planned nature have been carried out to reduce the number of unemployed and increase employment. Strategies have been adopted, including the employment strategy and national plans to bind the economic development to job creation.

The inherited substantial amount of various social benefits, enjoyed by the population at the time of socialism, led to a kind of turn during the transition period. On the one hand, people expected to continue to take advantage of the social benefits. On the other hand, the budgetary constraints, the poor financial situation of enterprises, and the uncertainty of managerial staff regarding their own future and the future of the organization proved to be an obstacle to their preservation.

Practically, the cost of these benefits increased the cost of labour, reduced profits, deteriorated the economic conditions of transforming the state-owned enterprises, while the newly established small private enterprises often lacked practice and desire or were unable to stimulate and motivate the staff. 
For the first time in 1991, the country started negotiating wages in contracting both individual and collective labour relations. A corresponding act by the government created three levels of formation of wages: national - for determining the minimum wage for the country, the types and the minimum amount of additional payments for work (for continuous work, overtime, etc.); collective labour agreements at sectoral and branch levels and at enterprise level; individual employment relationships.

Based on the legislation and the relevant enactments, the form of employment was fundamentally changed as well - by negotiation between the two parties of employment relations, not as it was before - unilaterally, by order of the respective manager of the enterprise. During these years of transition, the existing situation on the labour market predetermined the use of fixed-term contracts in employment (with maximum duration of three years in conformity with the current legislation). The practice and the specific situation on the respective labour markets widely approved short-term employment contracts (up to a year), employment not based on a labour agreement but on the so-called freelance contracts, employment without any labour agreement, without social security, etc.

During the years of transition to a market economy, the foundations of industrial relations, which was totally unknown and undeveloped at the time of socialism, were built. Being founded in the early years (1989-1990) they were developed and enriched in subsequent years. The principle of tripartism in human resource management at a national level was legislatively approved, the principle of tripartite partnership was determined (regulation of labour and social security relations and issues related to the living standards of population), the country's partnership with the employees' representative organizations (consultations and cooperation) was regulated, and the basic criteria for the representative character of the organizations of workers and employers (membership, representation of sectors, availability of national and regional structures) were determined. The institutions of industrial relations in Bulgaria were established in the form of tripartite cooperation councils (bipartite in enterprises). For this purpose, the rich experience of the European countries and the relevant conventions and recommendations of the International Labour Organisation (ILO) were used.

The provision of guarantees for the realization of the fundamental rights of workers required preparation and the adoption of a number of specific laws and the development of relevant institutions, funds and other conditions on their basis. Due to the inability of the National Assembly, on the one hand, for this relatively short period of time to prepare and adopt the numerous acts in the sphere of labour and social protection of population, and on the other hand - due to the need to adopt a number of laws in other fields of public life, the respective governments prepared and adopted a number of bylaws (decrees, regulations, etc.) in the field of: the labour market - establishment and development of its institutions, insurance and unemployment assistance, stimulation of unemployed and employers to increase employment, vocational training and qualification, etc.; social insurance - both for the employed and self-employed, entrepreneurs, freelancers and others; social assistance and social care; health care; education; remuneration; working conditions, etc. On this basis, the respective centrally governed institutions and regional structures were also developed.

The development of the labour market followed the basic trends in the economic development restructuring, privatization, liquidation of inefficient industries and activities. Throughout the first period, there was a high labour supply and extremely limited demand. Thus, the low employment and the high unemployment rates became a significant social problem for successful EU integration. The changes in production volumes affected the unemployment and employment rates of the population.

In the process of the complex market restructuring of the Bulgarian economy since the late 1980s, specific factors of the actual situation have been generated and activated. During the first period they hampered economic growth, caused deterioration and even individual deformations in some key macroeconomic relations and proportions. During this period the liberalization of trade and prices was carried out and the painful and protracted reforms in the agricultural sector began.

The quantitative determination of the dependence outlines the lagging effect of unemployment, which resulted in a change, about three times weaker in its rate as compared to the relative change in GDP. This was mainly related to the impact of three factors. If interpreted more widely and updated, these factors reveal some obvious or hidden, indirect signs of unemployment, employment and labour productivity; hardly surmountable discrepancies between the statistically reported and the actual dimensions of unemployment. These factors include the following major impacts (Terziev, 2019a-k):

In cases of a significant and prolonged decline in production the process of dismissing workers is accelerated, although this process could run with different intensity. The unemployment rate increases at a slower pace (not similar), because for different reasons, less (but not all) of the total number of dismissed workers additionally join the unemployment line. 
Some of the redundant workers orient relatively quickly to self-employment, entrepreneurship (mostly in small businesses), others refuse to participate in labour activities, i.e. join the group of the economically inactive individuals.

Any significant and permanent decrease in production affects the length, forms and nature of employment. The number of individuals employed part-time increases. Because of the reduction in the volume of production due to a decrease in revenues and profits, organizations seek to reduce costs in order to quickly overcome the situation. Very often this results in a decrease in labour productivity and GDP growth rate. Part-time employment can be regarded as a form of flexible employment, an attainment of freedom for individuals with regard to the length of their working time, as well as an 'intermediate' labour indicator which is formed on the boundary between employment and unemployment, because human resources are not used sufficiently, workers receive irregular, significantly less and unsatisfactory payment. Thus, although formally employed, part of the employed may be defined as hidden unemployed. Practically, especially during the first period of the transition, the employment in many enterprises did not comply with the definition of employment, the hours of work, the labour productivity and the receipt of remuneration did not match the established standards. The employment of these people was more limited and unsteady than the regular. This happens mainly in the case of deterioration of the overall economic growth rates, production limits imposed on individual enterprises (markets, supplies, cooperated supplies, etc.), resulting in deteriorated production and financial results and an increased possibility of mass dismissals from work (redundancies, layoffs).

The informal economy and employment were significantly developed along with the notable increase in the insecurity of the employed and those who had lost their jobs.

Bulgaria registered the highest decline in employment as follows: $1989-2000$ a decrease by $34.3 \%$, in Romania - by 17\% (1987-1990), in Hungary - by $9 \%$ (19921998), in the Czech Republic - by only $4 \%$ (1985-1993)12. In 2002 the number of the employed in Bulgaria was one-third less than the number of the employed in 1989 mainly due to workforce reduction in the industrial production. The rise in employment in construction and services failed to compensate for the mass layoffs in the industrial sector.

In order to avoid taxation or due to financial distress, irregular income and the uncertain future, some of the organizations did not account for the full amount of goods manufactured or the contracted transactions and sales. This effectively reduced the volume of the country's GDP. For households, the relatively high income from household production kept stable.

In the modern structure of the Bulgarian economy, the sphere of services, whose share over the years has been approximately $60 \%$, is of crucial importance. These industries possess a scope for development and, on the other hand, they have a relatively high potential to increase employment, because they are more labourintensive. However, they require and hire more workers with lower education and without the appropriate professional training, for lower payment, under fixed-term or freelance contracts or without contracts at all, for seasonal or temporary employment.

The industry branch, most affected by the process of privatization and reorganization of the corporate activity, gradually overcame its lagging behind and already predisposed to increased employment. Since 2005 the number of employed in the manufacture of food products, textiles and clothing, leather processing, wood and others has been increasing due to the predominant development of activities with higher labour consumption.

Small and medium-sized enterprises with limited opportunities to generate jobs and growth prevail. They often change the people employed, i.e. they have a high turnover of employees.

The unfavourable situation is predetermined by the choice of models and approaches for economic reforms and their slow and inconsistent implementation (Terziev, Kanev, 2019; Terziev, 2019a-k; Terziev, 2018-d; Terziev, Georgiev, 2018e-f; Terziev, Arabska, 2014; Terziev, 2015-b; Terziev, Arabska, 2016a).

\section{CONCLUSION}

The main conclusion that can be made is that the implementation of special employment programmes is one of the alternative solutions for reducing the tensions in the labour market. Their implementation, together with local regional initiatives and programmes, has the potential to increase employment and reduce unemployment.

To sum up, the restructuring of the economy continues and the efforts should be directed at improving its efficiency and competitiveness, as well as at limiting the budget sector and especially the increase in its capacity. Employment policies can increase their capacities if they become long-term and more closely 
linked to national and regional economic development plans (Terziev, 2019).

\section{REFERENCE LIST}

Georgiev, Marin. (2016). Obshtestvenoto i ikonomichesko razvitie v konteksta na sotsialnite politiki. // Spisanie za nauka „Novo znanie“. Visshe Uchilishte po Agrobiznes i Razvitie na Regionite, 5, 2016, N 4, str. 26-41, ISSN 2367-4598 (Online), (Print) ISSN $1314-5703$ (Георгиев, Марин. Общественото и икономическо развитие в контекста на социалните политики. // Списание за наука „Ново знание“. Висше училище по агробизнес и развитие на регионите, 5, 2016, N 4, стр. 26-41, ISSN 2367-4598 (Online), (Print) ISSN 1314-5703.

Georgiev, Marin. (2017). Sbalansirovannaya karta kak alyternativa malogo biznesa. // Innovatsionnie tehnologii v nauke novogo vrmeni, Sbornik statey Mezhdunarodnoy nauchno - prakticheskoy konferentsii 1 fevralya 2017 g., Ufa NITS AETERNA, Chasty 1, 2017, s. 43-49, ISBN 978-5-00109004-5, ISBN 978-5-00109-007-6 (Георгиев, Марин. Сбалансированная карта как альтернатива малого бизнеса. // Инновационніе технологии в науке нового врмени, Сборник статей Международной научно - практической конференции 1 февраля 2017 г., Уфа НИЦ АЭТЕРНА, Часть 1, 2017, с. 43-49, ISBN 978-5-00109-004-5, ISBN 978-5-00109-007-6).

Georgiev, Marin. (2017a). Impacts of active social programs on labor market. // Mezhdunarodnayy nauchnayy zhurnal „Innovatsionnaya nauka“. NITS Aeterna, N 02-1, 2017, pp. 139-143, ISSN 24106070 (Georgiev, Marin. Impacts of active social programs on labor market. // Международный научный журнал „Инновационная наука“. НИЦ Аэтерна, N 02-1, 2017, pp. 139-143, ISSN 2410 6070).

Terziev, V., Kanev, D. (2019). Modern developments in behavioral economics. // Smart Technologies and Innovations in Design for Control of Technological Processes and Objects: Economy and Production Proceeding of the International Science and Technology Conference „FarEastCon-2018” Volume 138, October 2-4, 2018, Vladivostok, Russian Federation, pp. 10-23, 2019, (Print) ISBN978-3-030-15576-6, (Online) ISBN978-3-030-15577-3.

Terziev, Venelin. (2019a). Provision of integrated employment and social assistance services in Bulgaria. // Smart Technologies and Innovations in Design for Control of Technological Processes and Objects: Economy and Production Proceeding of the International Science and Technology Conference „FarEastCon-2018” Volume 138, October 2-4, 2018, Vladivostok, Russian Federation, pp. 24-39, 2019, (Print) ISBN978-3-030-15576-6, (Online) ISBN978-3-030-15577-3.

Terziev, Venelin. (2019b). Problems of control in the social sphere. // INTCESS 2019- $6^{\text {th }}$ International Conference on Education and Social Sciences, 4-6 February, 2019, Dubai, International Organization Center of Academic Research, Istanbul, Turkey, pp. 577-593, ISBN: 978-605-82433-5-4.

Terziev, Venelin. (2019c). The criterion "competence" in the economic sector. // INTCESS 2019- $6^{\text {th }}$ International Conference on Education and Social Sciences, 4-6 February, 2019, Dubai, International Organization Center of Academic Research, Istanbul, Turkey, pp. 1241-1247, ISBN: 978-605-824335-4.

Terziev, Venelin. (2019d). Social policy and labor market development in Bulgarian transition period. // INTCESS 2019- $6^{\text {th }}$ International Conference on Education and Social Sciences, 4-6 February, 2019 , Dubai, International Organization Center of Academic Research, Istanbul, Turkey, pp. 703-714, ISBN: 978-605-82433-5-4.

Terziev, Venelin. (2019e). Theoretical basis of development of labor market and social policy in the republic of Bulgaria. // INTCESS 2019- $6^{\text {th }}$ International Conference on Education and Social Sciences, 4-6 February, 2019, Dubai, International Organization Center of Academic Research, Istanbul, Turkey, pp. 715-726, ISBN: 978-605-82433-5-4.

Terziev, Venelin. (2019f). The problem of social efficiency- Indicators for social efficiency. // INTCESS 2019$6^{\text {th }}$ International Conference on Education and Social Sciences, 4-6 February, 2019, Dubai, International Organization Center of Academic Research, Istanbul, Turkey, pp. 669-678, ISBN: 978605-82433-5-4. 
Terziev, Venelin. (2019g). Experiencing social policy development and efficiency measurment. // INTCESS 2019- $6^{\text {th }}$ International Conference on Education and Social Sciences, 4-6 February, 2019, Dubai, International Organization Center of Academic Research, Istanbul, Turkey, pp. 679-686, ISBN: 978605-82433-5-4.

Terziev, Venelin. (2019h). Efficiency and assessment of social technology. // INTCESS 2019- $6^{\text {th }}$ International Conference on Education and Social Sciences, 4-6 February, 2019, Dubai, International Organization Center of Academic Research, Istanbul, Turkey, pp. 687-694, ISBN: 978-605-82433-5-4.

Terziev, Venelin. (2019i). Conceptual framework of social adaptation. // INTCESS 2019- $6^{\text {th }}$ International Conference on Education and Social Sciences, 4-6 February, 2019, Dubai, International Organization Center of Academic Research, Istanbul, Turkey, pp. 494-503, ISBN: 978-605-82433-5-4.

Terziev, Venelin. (2019j). The dependence social adaptation- socialization. // INTCESS 2019- $6^{\text {th }}$ International Conference on Education and Social Sciences, 4-6 February, 2019, Dubai, International Organization Center of Academic Research, Istanbul, Turkey, pp. 478-485, ISBN: 978-605-82433-5-4.

Terziev, Venelin. (2019k). Social activity and human resources as social development factors. // INTCESS 2019- $6^{\text {th }}$ International Conference on Education and Social Sciences, 4-6 February, 2019, Dubai, International Organization Center of Academic Research, Istanbul, Turkey, pp. 546-553, ISBN: 978 605-82433-5-4.

Terziev, Venelin. (2018). The active model of a social programme and its strategic advantage .// ADVED 2018- $4^{\text {th }}$ International Conference on Advances in Education and Social Sciences Abstracts \& Proceedings, 15-17 October 2018- Istanbul, Turkey, International Organization Center of Academic Research, www.ocerints.org, Istanbul, Turkey, 2018, pp. 189-203, ISBN: 978-605-82433-4-7.

Terziev, Venelin. (2018a). Active social programs development in Bulgaria: contemporary challenges and social management instruments. // ADVED 2018- $4^{\text {th }}$ International Conference on Advances in Education and Social Sciences Abstracts \& Proceedings, 15-17 October 2018- Istanbul, Turkey, International Organization Center of Academic Research, www.ocerints.org, Istanbul, Turkey, 2018, pp. 149-163, ISBN: 978-605-82433-4-7.

Terziev, Venelin. (2018b). Social assistance services and integrated employment in Bulgaria. // ADVED 2018- $4^{\text {th }}$ International Conference on Advances in Education and Social Sciences Abstracts \& Proceedings, 15-17 October 2018- Istanbul, Turkey, International Organization Center of Academic Research, www.ocerints.org, Istanbul, Turkey, 2018, pp. 164-177, ISBN: 978-605-82433-4-7.

Terziev, Venelin. (2018c). Impact of the labor market policies for ensuring employment. // ADVED 2018- $4^{\text {th }}$ International Conference on Advances in Education and Social Sciences Abstracts \& Proceedings, 1517 October 2018- Istanbul, Turkey, International Organization Center of Academic Research, www.ocerints.org, Istanbul, Turkey, 2018, pp. 178-188, ISBN: 978-605-82433-4-7.

Terziev, Venelin. (2018d). Importance of human resources to social development. // ADVED 2018- $4^{\text {th }}$ International Conference on Advances in Education and Social Sciences Abstracts \& Proceedings, 1517 October 2018- Istanbul, Turkey, International Organization Center of Academic Research, www.ocerints.org, Istanbul, Turkey, 2018, pp. 204-212, ISBN: 978-605-82433-4-7.

Terziev, V., Georgiev, M. (2018e). A strategic framework for the development of social entrepreneurship in Bulgaria. // Knowledge - International Journal, August 2018, Institute of Knowledge Management, Skopje, Macedonia, 25, 2018, N 1, pp. 23-34, ISSN 1857-923X (for e-version), ISSN 2545 - 4439 (for printed version).

Terziev, V., Georgiev, M. (2018f). Support for the development of social entrepreneurship in Bulgaria. // Knowledge - International Journal, September, 2018, Institute of Knowledge Management, Skopje, Macedonia, 26, 2018, N1, pp.57-74, ISSN 1857-923X (for e-version), ISSN 2545 - 4439 (for printed version).

Terziev, V., E., Arabska. (2014). Assessment of active social policies' impacts on labor market in the Republic of Bulgaria. Kolektivnaya monografiya "Sotsialyno-ekonomicheskie i pravovay razvitiya ekonomiki“, Ufa, Aeterna. Rossiya, 2014. ISBN 978-5-906769-97-8, str. 3-57 (Terziev, V., E. Arabska. (2014). Assessment of active social policies' impacts on labor market in the Republic of Bulgaria. Колективная монография „Социально-экономические и правовы развития экономики“, Уфа, Аэтерна. Россия, 2014. ISBN 978-5-906769-97-8, стр. 3-57).

Terziev, Venelin. (2015). Impact of active social policies and programs in the period of active economic 
transformations in Bulgaria, „East West” Association for Advanced Studies and Higher Education, Vienna, 2015, ISBN 78-3-903063-44-0, 434 p.

Terziev, Venelin. (2015a). Assessment of active social policies impact of social policies on transformation processes in bulgarian economy, Moscow, 2015, Publisher „Перо“, 110 p.

Terziev, Venelin. (2015b). Opportunities for improving the efficiency of the social adaptation of servicemen discharged from military service in Bulgaria:- Novosibirsk: Publisher CRNS, 2015. ISBN 978-5-00068402-3, $270 \mathrm{p}$.

Terziev, V., E., Arabska. (2016a). Effektivnoe vliyanie na raynok truda posredstvom uluchsheniya realizatsii sotsialynoy politiki. Novosibirsk: Izdatelystvo TSRNS, 2016. ISBN 978-5-00068-496-2, $312 \mathrm{str}$ (Терзиев, В., Е. Арабска. (2016а). Эфрфективное влияние на рынок труда посредством улучшения реализации социальной политики. Новосибирск: Издательство ЦРНС, 2016. ISBN 978-5-00068-496-2, 312 стр). 